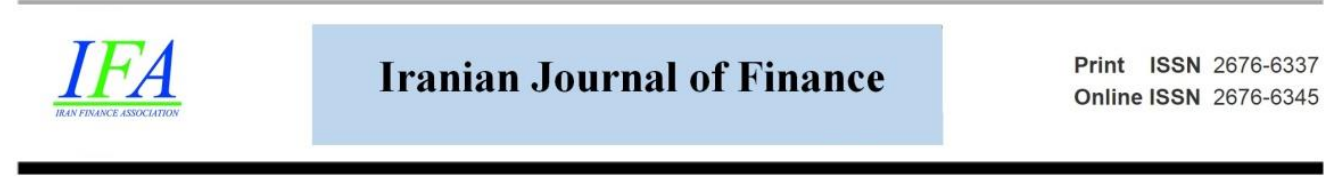

\title{
Choosing Influential Dimension of Mindfulness of Auditors' Professional Judgments Based on Social Pressure: An Analysis Based on Rough Theory
}

\section{Seyed Mohammad Soleymani}

Ph.D. Candidate, Department of Accounting, Islamic Azad University, Shahrood Branch, Shahrood, Iran. (Email: mohammadsoleimany22@gmail.com)

\section{Farhad Dehdar*}

*Corresponding Author, Assistant Professor, Department of Accounting, Islamic Azad University, Shahroud Branch, Shahroud, Iran. (Email: farhaddehdar@yahoo.com)

\section{Mohammadreza Abdoli}

Associate Professor, Department of Accounting, Islamic Azad University, Shahroud Branch, Shahroud, Iran. (Email: mra830@yahoo.com)

Document Type: Original Article

Received: 2021/04/07
Accepted: 2021/10/28
2022, Vol. 6, No. 2. 135-166.

Published: 2022/02/18

\begin{abstract}
The growth and complexity of society justify the need for relevant economic information, information systems, and information-generating processes, and the need for auditing as part of the information reporting process increases. This has affected the professional functions of auditors. The purpose of this research is to choose the influential dimension of mindfulness of auditors' professional judgments based on social pressure analysis based on Rough Theory. The methodology of this research is mixed and it has been used by Meta-synthesis, Delphi and Rough Theory. The target population was the qualitative, similar research and academic experts in the field of accounting. However, the target population in a small number of 19 audit partners had
\end{abstract}


more than 5 years of work experience, which is acceptable from the statistical population due to the requirement of Ruff theory analysis. In this study, based on the Meta-synthesis analysis of selected researches, 4 propositions of pressures based on social compliance and 3 components of auditors' professional judgment were determined. The results in this section show that the most effective proposition of social compliance pressures was the market pressure proposition, which affects the inferential consciousness of auditors in their professional judgment and violates the auditors' mental functions such as skepticism and objectivity.

Keywords: Auditors' Mindfulness, Pressures of social conformity, Rough Theory

DOI: https://doi.org/ 10.30699/IJF.2021.279873.1214 Publisher: Iran Finance Association

Copyright: author(s) Type of License: Creative Commons License (CC-BY 4.0)

\section{Introduction}

The growing expansion of economic units, the development of the information society, and the existence of conflicts of interest have made the need for effective oversight of auditors' performance all the more important, because users need a variety of information to make decisions, including financial information and verification by auditors (Wardhani, 2019). It is important to note that auditing, as one of the most important pillars in the capital market as any profession, faces many challenges, including the complexity of rules and standards; the Existence of high social expectations, etc. In fact, the codified standards in this field emphasize maintaining the independence of the auditor as a primary basis for reviewing the performance of owners (Yarahmadi, 2018). But the question is, is it possible to maintain the full independence of auditors because of such standards? Do auditors make judgments based solely on philosophical and professional insights, regardless of the pressures of the profession? The existence of such questions raises the need to pay more attention to the hidden dimensions of auditors' functions. In fact, auditors will face pressures and constraints due to the environment in which the level of substantial material benefits circulates. An important part of these constraints is the pressures that are imposed on auditors in various forms, and this will affect their behavioral and professional performance. Conformity is considered a social pressure that may not necessarily have specific themes in the audit 
community. But over time, its negative dimensions can affect the professional values of auditing, and enable auditors based on the contradiction between professional characteristics and dimensions of social identity theory to consider values that violate auditory skepticism (Brink et al, 2016). Social conformity is a type of environmental and normative influence (Sadeghi Fasaei and Aminian, 2016) that includes changes in beliefs or behavior in auditors to eventually lead to the auditor's conformity with the level of value and norm that has gradually penetrated the auditing profession. It should be noted that the pressure of social conformity based on changing value-based patterns in auditing eventually causes the auditor to succumb to pressures, which causes other auditors to follow the established norm and this issue in its negative form can undermine the independence of auditors (Nasution and Ostermark, 2012). Clayton and Van Staden (2015) in a study examined the role of social conformity pressures on the level of professional decisions of auditors and accountants and stated that social conformity while emphasizing utilitarian and individual values, leads to the formation of behavioral and perhaps customary norms influence the generalities of codified standards in this field in the face of functional realities in the auditing profession. On the other hand, Ali and Abazi (2018) in a study aimed at the effect of social compliance on professional judgment, confirmed the undeniable level of social pressures created on the audit profession. These results show that the level of social pressures resulting from conformity with auditors' performance cannot be ignored. Because part of the impact of such pressures can affect the conscious mind functions of auditors as a basis for professional skepticism, which is in fact the purpose of this research. It should be noted that regardless of the existence of standards in promoting the level of auditor independence, the existence of mental abilities of individuals in accepting independence is an important point. In fact, the auditor's ability to be mindful of behavioral and functional skills such as independence demonstrates the auditor's ability to maintain professional neutrality and skepticism that gives confidence in the review of owners' financial statements. And in terms of technical competencies, it has a significant effect in improving the level of information symmetry in the capital market. In addition to increasing the reliability of financial statements, such features reduce the unfairness of information and give credit to the capital market. But various threats from the client as well as from the auditor itself on the one hand, and social pressures, cultural factors and organizational ethics, on the other hand, has weakened the position of auditors in terms of professional independence and, in a way, has challenged the most important feature of auditing and the accreditation profession (Segal, 2019). In fact, mindfulness refers to the auditor being aware of the thoughts, behavior, emotions, etc., and 
focusing best on the financial performance facts of the clients, which intends to study it in terms of intrinsic, professional and social duties (Mollanazari and Shams, 2016). Therefore, in this study, the level of mindfulness of auditors against the pressures of social conformity is analyzed based on interpretive ranking analysis. This research tries to identify the components and propositions related to the research variables, to evaluate the level of the most influential pressures caused by conformity on the auditors' mindfulness as a basis for skepticism. So the main question is what is the most influential dimension of mindfulness of judging the auditors' profession based on pressures based on social conformity?

\section{Literature Review}

\section{Mindfulness of Auditors' Professional Judgments}

Mindfulness in all disciplines combines the basic elements of logical reasoning with the elements needed to make sound judgments. In mindfulness auditing, it is a kind of individual insight of the auditor towards the nature and content of professional work based on evidence and documents. In fact, mindfulness in the auditing profession is associated with a curious and creative approach. And this is exactly what auditing standards emphasize the need to use professional skepticism in audit planning. For example, paragraph 15 of Iranian Auditing Standard No. 200 briefly mentions the role of skepticism and professional care in the distortion of financial statements. According to paragraph 15 of Standard No. 200, professional doubts require the auditor to be aware of issues such as conflicting audit evidence, the possibility of fraud, and so on. Also, in accordance with paragraphs T-17, T-18 and T-19 of the said standard, professional skepticism is necessary for the critical evaluation of audit evidence. A professional skeptical attitude means that the auditor, with a questioning mind, makes a critical assessment of the validity of the audit evidence obtained (Tahriri and Piri Saqerloo, 2016). In fact, mindfulness is conceptually aligned with professional skepticism and has created a positive and normative approach in the auditing profession, and by seeking to improve the quality of financial performance in the capital market by challenging traditional and empirical methods in auditing. The basic premise of critical auditing is that society can be different from what it is, and the conscious behavior of auditors if it follows critical theories, has the ability to change or improve social trust in the capital market (Shabahang, 2012). Therefore, the existence of mindfulness in auditing can have a wide range conceptually and semantically, but it contains a clear and obvious concept and that is a reflection 
on the decision and better understanding of the issue during the decision (Abednazari et al, 2018). The concept of mindfulness in auditing can be examined in more detail. In fact, mindfulness in auditing acts as a process that includes the auditor's insight, ability, expertise and perception to better understand the content and subject matter to make decisions. The existence of subjective alignment and skill capability is a measure that, if it is balanced in the auditor's thoughts and perceptions when reviewing financial statements, can contribute to the auditor's motivation and inference to have a different understanding of the issues and challenges ahead. It seems that based on the worldview that exists in mindfulness, it is expected that through the adoption of mindfulness in the auditing profession, social relations in various forms such as social trust, economic and cultural relations will take a more desirable shape and increases the level of power of knowledge and perception in the interactive processes between the auditor and the owners and the capital market (Glover et al, 2018).

\section{Social Pressure in Auditing Profession}

Social conformity is a type of social influence that involves a change in belief or behavior that ultimately leads to individual adaptation to a group. This change is in response to real pressure (including the physical presence of others) or imaginary pressure (including the pressure of norms or social expectations) by a group (Sadeghi Fasaei and Aminian, 2016). Social conformity can also simply be defined as "surrender to group pressure" (Ali and Abazi, 2018). Group pressure can take many forms, such as bullying, persuasion, harassment, criticism, and so on. Adaptation is also known as majority influence (or group pressure) (Wang et al, 2018). The term social harmony is often used to denote a compromise or agreement with a situation that the majority agrees with. This may be due to the desire to "adapt" or be liked (normatively) or due to the desire to behave correctly (in terms of information) (Mahmoodi Nasab et al, 2017). Norms as a consequence of social conformity are a kind of institutionalizing of value in a profession such as the auditing profession, which gradually includes the field of learning among auditing peers. And basically honors such as honesty, fulfillment of obligations; social Identity; Negotiations, etc. probably affect the audit (Mahmoodi Nasab et al, 2017). Putnam (1996), as one of the pioneers of approaches based on possible pressures of conformity, believes that social norms resulting from conforming values have a great impact on the transformation of social capital at every level of society and its stakeholders and this causes the level of expectations and procedures of needs to change over time. The auditing profession, as one of these areas, is also greatly 
affected by social conformity, because the lack of content adaptation and screening of auditors to enter this field has greatly reduced the level of social identities. And this issue can cause the auditor to replace ethical values with a new form of norms with negative value due to tolerance with owners, which has been considered according to the emphasis of auditing standards (Valiyan et al, 2020). Based on the literature review, the research questions are:

1. What are the components of auditors' professional judgment mindfulness?

2. What are the propositions of pressures based on social conformity in the auditing profession?

What is the most influential dimension of auditors' professional judgment mindfulness based on pressures based on social conformity?

\section{Research Review}

Bentley et al (2020) conducted a study entitled "Assessing the Impact of Auditors 'Critical Thinking Level on Commenting on Operators' Operational Decisions". This study, which was conducted with the participation of 217 auditors with experience and professional background, showed that applying the level of critical thinking of auditors in commenting can help increase the decision-making power of managers and cause the level of potential risks of the company in the face of uncertainties to be controlled to some extent and the interests of stakeholders are protected. The existence of this approach is considered as an advantage of the audit market and this issue increases the level of dynamics of transparent information transmission to decision-makers and shareholders. Wu et al (2020) conducted a study on the quality of financial statement disclosure under the influence of auditors' mindfulness. In this study, 116 comments of auditors of the previous year (2017) who had a high level of mindfulness about companies were examined. Over a one-year period in 2018, the study assessed the existence of critical auditor comments on financial performance in 2017 for 2018 and the disclosure of information in the form of financial statements for the following year, the results of which showed that critical thinking to strengthen the level of transparency in the disclosure of companies' financial statements. Polychronidou et al (2020) conducted a study entitled "Cultivating the Voluntary Circulation of Auditors in Greece" with the aim of expanding mindfulness. In this study, the level of programs of upstream institutions as a determinant of the path of performance culture of companies to increase the level of transparency was examined through content analysis. Which aims to assess the level of mindfulness in the form of three interpretive, intuitive, and inferential levels. The results showed that increasing the voluntary level of auditors 'turnover by companies can improve all three levels 
of auditors' awareness. Olojede et al (2020) conducted a study entitled "Covering the Audit Expectation Gap by Developing Reasoning Thinking Functions". The purpose of this study was to improve the level of thinking capacity of auditors beyond the specialized dimensions and based on covering the social interests of stakeholders to improve the level of information transparency and performance of companies. This study was conducted in Nigeria and examined the content of the dimensions of the expectation gap between auditors and stakeholders. The four main components of cultural dimension, behavioral dimension, environmental dimension and religious dimension were among the factors that stimulated the level of auditors' functions to cover more transparency by using reasoning. The results showed that the existence of reasoning thinking functions will cause the dynamics of auditors' decision-making functions to cover the level of critical thinking. Segal (2019) conducted a study entitled "Auditors' Insight and Mental Insight into Professional Judgment". In this study, auditors with more than 5 years of experience in auditing in South Africa as a target community participated and the research tool was a questionnaire. In order to analyze and test the research hypotheses, Partial Least Squares (PLS) analysis was performed based on Smart PLS software. The results showed that raising the level of mindfulness in the form of auditors 'insights and mental insights can increase the level of auditors' professional judgments. Lohse et al (2018) conducted a study entitled "Stress factors affecting the ability of auditors' individual mindfulness in decision making." In this study, which was conducted over a period of one year, it was found that the audiences' mindfulness capabilities are influenced by professional attitudes which promote a culture of impartiality and skepticism in the auditing profession and helps auditors make fact-based decisions when commenting and judging. Bakhtiari et al (2020) conducted a study entitled "Orbital Relationship and Auditor Independence: A Test of Social Relationship Theory". According to the theory of social relations, this study examines the relationship between orbital relationship as a social component and auditor independence. For this purpose, in 2017, 249 questionnaires were randomly distributed and collected among auditors working in the auditing organization and member organizations of the Iranian Society of Certified Public Accountants, and the data obtained from them were analyzed using the structural equation model. In this study, the independent variable is the communicational behavior relationship and the dependent variable is the independence of the auditor. The results show that the greater the tendency of auditors to have a communicational behavior relationship, the more likely it is that auditors will violate their independence, even with professional supervision. This study showed that communicational behavior culture is 
considered as an influential factor in the relationship between the auditor and the client in the country's audit market. In order to maintain relationships with their owners, auditors try to make their judgments in accordance with their relationships with their owners. This suggests that communication and social connections can have a negative impact on audit independence and quality. Valiyan et al (2019) conducted a study entitled "Designing a Professional Skepticism Model Based on the Mindset and Attitude of Auditors: Using Grounded Theory Analysis". The methodology of this research is a part of developmental research in terms of result, exploratory research in terms of purpose and qualitative work in terms of method of implementation. Based on qualitative methodology through grounded theory analysis (grounded theory analysis) and by conducting interviews, the necessary data were collected and open, selective and pivotal coding was done and finally, the research model was designed based on the theoretical framework. Findings showed that the mentality and attitude of professional skeptics are influenced by a set of individual psychological factors and social and cultural causes that play a role in shaping the skepticism of auditors. It was then found that the consequences of auditors' skepticism can have consequences such as critical evaluation of evidence and cognitive evaluation. On the other hand, the consequence of the auditors' skeptical attitude can also lead to emotional stability and professional judgments.

\section{Research Methodology}

Given the existence of three basic results; the purpose and type of data in the methodology of any research should be stated. This research is considered developmental in terms of results because the concepts related to the analysis of the mindfulness dimension of auditors' professional judgments based on pressures of social compliance do not theoretically have a coherent framework. And since this research seeks to develop the theoretical basis of this concept in the auditing profession, it is considered a development from this perspective. Also, based on the purpose, this research is among the descriptive researches to explain the desired phenomenon in the auditing profession. Finally, in terms of logic, data collection is inductive-deductive, because in the qualitative part, first relying on the inductive approach, the theoretical foundations of mindfulness and social conformity are analyzed, and then the components and propositions identified in the community become the target. In this research, which is hybrid research, Meta-synthesis is used in the qualitative part. Metasynthesis includes steps to arrive at components and propositions, perhaps the most important of which are the Sandlowski and Barros (2008) process steps, 
ranging from recognizing the root cause of the problem to formulating a research question to providing a specific model based on identifying components and propositions from research results. The past is covered by the participation of panel members. Also, in a quantitative part, through the analysis of Rough theories, the most effective propositions identified in the form of a hierarchical model are determined. Then, based on Delphi analysis, to determine the theoretical adequacy according to the two criteria of mean and agreement coefficient, an attempt is made to analyze the propositions back and forth between experts.

\section{Statistical population and Sampling method}

The statistical population of this study consists of two parts, one is the qualitative part and the other is the quantitative part. The statistical population in the qualitative section includes 13 specialists and experts in the field of accounting at the university level, who have a specialized and scientific approach in this regard by conducting scientific research in a similar field. These individuals were selected through a homogeneous sampling method because the aim was for the people participating in this section to have a theoretical view of the research topic. Also based on Meta-synthesis, in this part of the research conducted in sites such as University Jihad (SID) in Iran; Iran Magazine Database (MAGIRAN) Iran; Islamic Computer Science Research Center (NOORSOFR) Iran; International Science direct; Emerald insight reference and Online Literary reference were used to determine components (pressures based on social conformity) and research propositions (capacities of mindfulness). In the second phase, in order to perform the interpretive ranking analysis section, 19 auditing partners with more than 5 years of work experience were asked to respond to the identified components and indicators of the quality section and respond to the matrix questionnaires. In fact, since this method is an analysis based on the analysis of complex systems at certain levels and should be based on a specific criterion such as experience or expertise by participants, which due to the lack of a lot of incomprehensible answers, the cross-matrix questionnaire with participation 15 It takes up to 30 people. Researchers such as Zhang et al (2015); Shyng et al (2007) and Pawlak (2005) predicted the optimal sample size selection in the range of 15 to 25 people. And stated that the basis for selecting the sample population was the available sampling method according to the filters in accordance with the nature of the research. 


\section{Research validity}

To confirm the validity of the constructed questionnaires, the content validity (CVR) method was used, based on which 10-panel members were asked to use evaluate three criteria as "necessary"; "useful but not necessary" and "unnecessary" statements. Each participant had to choose one of the above three options to confirm the validity of the research. In the end, it was determined that all the propositions were above the set standard (CVR) and were approved.

\section{Procedures of the Rough Set Theory}

The Rough sets introduced by Pawlak (1982) for the first time, is a valuable mathematical instrument in uncertainty conditions (Pawlak, 1982). After the Rough Set Theory, Zhai et al (2002) proposed the Rough numbers. A Rough number includes usually "Lower Limit", "Upper limit" and " Rough boundary interval" which depends only on the original data. So there is no need for supplementary data and this can get a better understanding of the experts' intended concepts and improve the decision making objectivity (Pawlak, 1982).

Suppose that "U" is a reference set including all members, "Y" is an arbitrary member of $U$ and $R$ sets belonging to "t class". $R=\{G 1, G 2, \ldots, G t\}$ which covers all members of $\mathrm{U}$. If these classes are in order as $\mathrm{G} 1<\mathrm{G} 2<\ldots<\mathrm{Gt}$, then $\forall \mathrm{Y} \in \mathrm{U} . \mathrm{G}_{\mathrm{q}} \in \mathrm{R} .1 \leq \mathrm{q} \leq \mathrm{t}$.

The Lower Approximation (Apr $(\mathrm{Gq})$ ), the Upper Approximation $\overline{\operatorname{Apr}}\left(\mathrm{G}_{\mathrm{q}}\right)$ and the Boundary Area (Bnd $(\mathrm{Gq})) 3$ belonging to class $\mathrm{Gq}$ are defined as follows:

$$
\begin{aligned}
& \underline{\operatorname{Apr}}\left(\mathrm{G}_{\mathrm{q}}\right)=U\left\{\mathrm{Y} \in \mathrm{U} \mid \mathrm{R}(\mathrm{Y}) \leq \mathrm{G}_{\mathrm{q}}\right\} \\
& \overline{\operatorname{Apr}}\left(\mathrm{G}_{\mathrm{q}}\right)=U\left\{\mathrm{Y} \in \mathrm{U} \mid \mathrm{R}(\mathrm{Y}) \geq \mathrm{G}_{\mathrm{q}}\right\} \\
& \operatorname{Bnd}\left(\mathrm{G}_{\mathrm{q}}\right)=U\left\{\mathrm{Y} \in \mathrm{U} \mid \mathrm{R}(\mathrm{Y}) \neq \mathrm{G}_{\mathrm{q}}\right\} \\
& =\left\{\mathrm{Y} \in \mathrm{U} \mid \mathrm{R}(\mathrm{Y})>\mathrm{G}_{\mathrm{q}}\right\} \cup\left\{\mathrm{Y} \in \mathrm{U} \mid \mathrm{R}(\mathrm{Y})<\mathrm{G}_{\mathrm{q}}\right\}
\end{aligned}
$$

Then $\mathrm{Gq}$ can be presented using a Rough number $\mathrm{RN}(\mathrm{Gq}) 4$ in its corresponding lower and upper limits: (Equations 4-6).

$$
\begin{aligned}
& \underline{\operatorname{Lim}}\left(G_{\mathrm{q}}\right)=\frac{1}{\mathrm{M}_{\mathrm{L}}} \sum \mathrm{R}(\mathrm{y}) \mid \mathrm{Y} \in \overline{\operatorname{Apr}}\left(\mathrm{G}_{\mathrm{q}}\right) \\
& \overline{\operatorname{Lim}}\left(\mathrm{G}_{\mathrm{q}}\right)=\frac{1}{\mathrm{M}_{\mathrm{U}}} \sum \mathrm{R}(\mathrm{y}) \mid \mathrm{Y} \in \overline{\operatorname{Apr}}\left(\mathrm{G}_{\mathrm{q}}\right)
\end{aligned}
$$


$\operatorname{RN}\left(G_{\mathrm{q}}\right)=\left\lfloor\underline{\operatorname{Lim}}\left(G_{\mathrm{q}}\right) \cdot \overline{\operatorname{Lim}}\left(G_{\mathrm{q}}\right)\right\rfloor$

Where MU and ML are respectively the values of members $\operatorname{Apr}\left(G_{q}\right)$, $\overline{\operatorname{Apr}}\left(\mathrm{G}_{\mathrm{q}}\right)$

It is clear that the lower and upper limits determine respectively the mean value of the elements related to upper and lower approximations and their difference is defined as "Rough Boundary Interval".

$\operatorname{IRBnd}\left(\mathrm{G}_{\mathrm{q}}\right)=\overline{\operatorname{Lim}}\left(\mathrm{G}_{\mathrm{q}}\right)-\overline{\operatorname{Lim}}\left(\mathrm{G}_{\mathrm{q}}\right)$

The Rough Boundary Interval expresses the ambiguity of "Gq", so that its larger value means more ambiguity, while the smaller value has more accuracy. So the subjective data can be expressed by the Rough numbers (Ima et al, 2008).

The gray hierarchy analysis process is one of the most famous and commonly used multiple decisions making which is able to measure the level of preferences' consistency and consider the tangible and intangible criteria. The gray relational analysis method is used to select the best choice based on the number of criteria. This method, like the Topsis technique and the Vikor technique, starts with a decision matrix but here in addition to the distinction between the positive and negative criteria, it also distinguishes between the most desirable value. In this research, because the experts' judgements were subjective and ambiguous, the gray hierarchy analysis process was used. In the following, the gray hierarchy analysis process is presented.

Step 1. Determine the goals, criteria and choices of the research and form the hierarchy structure.

Step 2. Prepare the pairwise comparison questionnaire and collect the experts' opinions.

Step 3. Using the concept of Rough theory to change the experts' preferences to interval numbers and form the interval pairwise comparison matrix like the Equation below:

$M=\left[\begin{array}{rrrr}\lceil 1.1\rceil & \left\lceil\mathrm{x}_{12}^{\mathrm{L}} \cdot \mathrm{x}_{12}^{\mathrm{U}}\right\rceil \ldots & \left\lceil\mathrm{x}_{1 \mathrm{~m}}^{\mathrm{L}} \mathrm{x}_{1 \mathrm{~m}}^{\mathrm{U}}\right\rceil \\ \left\lceil\mathrm{x}_{21}^{\mathrm{L}} \mathrm{x}_{21}^{\mathrm{U}}\right\rceil & \lceil 1.1\rceil \ldots & \left\lceil\mathrm{x}_{2 \mathrm{~m}}^{\mathrm{L}} \mathrm{x}_{2 \mathrm{~m}}^{\mathrm{U}}\right\rceil \\ & \cdot & & \\ & \cdot & \\ \left\lceil\mathrm{x}_{\mathrm{m} 1}^{\mathrm{L}} \mathrm{x}_{2 \mathrm{~m}}^{\mathrm{U}}\right\rceil\lceil & \ldots & & \lceil 1.1\rceil\end{array}\right]$

Where, $\mathrm{x}_{\mathrm{ij}}^{\mathrm{L}}$, Lower limit; $\mathrm{x}_{\mathrm{ij}}^{\mathrm{U}}$, Upper limit. (p.11) 
Before computing interval numbers, the inconsistency rate of the pairwise comparison questionnaires should be measured and if this rate is acceptable (below 0.1), we can compute the interval numbers.

Step 4. Calculate the weight of each of the research's criteria using the Equations (9) and (10)

$w_{i}=\left\lceil\sqrt[m]{\prod_{j=1}^{m} x_{i j}^{L}} \cdot \sqrt[m]{\prod_{j=1}^{m} x_{i j}^{U}}\right\rceil$

$\mathrm{w}_{\mathrm{i}}^{\prime}=\mathrm{w}_{\mathrm{i}} / \max \left(\mathrm{w}_{\mathrm{i}}^{\mathrm{u}}\right)$

Where we have: W1' is a normalized form. Finally, the weight of the research criteria is obtained (Zhu et al, 2015).

Step 1: In the Vikor method, the decision matrix is formed. Since in this research we have used the Gray Vikor method, the Vikor questionnaire completed by the experts must be first changed into the interval numbers using the Rough theory concept, and then performs calculations using the Gray Vikor method. In the following the Gray Vikor method is presented:

Step 1: form the interval decision matrix obtained from the Rough theory,

$\mathrm{D}=\left[\begin{array}{llll}\left\lceil\mathrm{f}_{11}^{\mathrm{L}} \mathrm{f}_{11}^{\mathrm{U}}\right\rceil & \left\lceil\mathrm{f}_{12}^{\mathrm{L}} \mathrm{f}_{12}^{\mathrm{U}}\right\rceil & \ldots & \left\lceil\mathrm{f}_{1 \mathrm{~m}}^{\mathrm{L}} \mathrm{f}_{1 \mathrm{~m}}^{\mathrm{U}}\right\rceil \\ \left\lceil\mathrm{f}_{21}^{\mathrm{L}} \mathrm{f}_{21}^{\mathrm{U}}\right\rceil & \left\lceil\mathrm{f}_{22}^{\mathrm{L}} \mathrm{f}_{22}^{\mathrm{L}}\right\rceil & \ldots & \left\lceil\mathrm{f}_{2 \mathrm{~m}}^{\mathrm{L}} \mathrm{f}_{2 \mathrm{~m}}^{\mathrm{U}}\right\rceil \\ \left\lceil\mathrm{f}_{\mathrm{n} 1}^{\mathrm{L}} \mathrm{f}_{\mathrm{n} 2}^{\mathrm{U}}\right\rceil & \left\lceil\mathrm{f}_{\mathrm{n} 2}^{\mathrm{L}} \mathrm{f}_{\mathrm{n} 2}^{\mathrm{U}}\right\rceil & \ldots & \left\lceil\mathrm{f}_{\mathrm{nm}}^{\mathrm{L}} \mathrm{f}_{\mathrm{nm}}^{\mathrm{U}}\right\rceil\end{array}\right]$

Step 2: determine the best (the most desirable) value fj* and the worst value fj- in each criterion of matrix D. For positive criterion (with the profit nature), the largest number shows the best value and the smallest value shows the worst value:

$$
\mathrm{f}_{\mathrm{j}}^{*}=\operatorname{Max}_{\mathrm{i}} \mathrm{f}_{\mathrm{ij}}^{\mathrm{U}} \cdot \mathrm{f}_{\mathrm{ij}}^{-}=\operatorname{Min}_{\mathrm{i}} \mathrm{f}_{\mathrm{ij}}^{\mathrm{L}}
$$

It is vice versa for negative criterion (with the expense nature):

$\mathrm{f}_{\mathrm{j}}^{*}=\operatorname{Min}_{\mathrm{i}} \mathrm{f}_{\mathrm{ij}}^{\mathrm{U}} \cdot \mathrm{f}_{\mathrm{ij}}^{-}=\operatorname{Max}_{\mathrm{i}} \mathrm{f}_{\mathrm{ij}}^{\mathrm{L}}$

In general, the best and the worst values are obtained as follows:

$\mathrm{f}_{\mathrm{j}}^{*}=\left\{\left(\operatorname{Max}_{\mathrm{i}} \mathrm{f}_{\mathrm{ij}}^{\mathrm{U}} \mid \mathrm{j} \in \mathrm{B}\right) \operatorname{or}\left(\operatorname{Min}_{\mathrm{i}} \mathrm{f}_{\mathrm{ij}}^{\mathrm{L}} \mid \mathrm{j} \in \mathrm{C}\right)\right\}$

$\mathrm{f}_{\mathrm{j}}^{-}=\left\{\left(\operatorname{Min}_{\mathrm{i}} \mathrm{f}_{\mathrm{ij}}^{\mathrm{L}} \mid \mathrm{j} \in \mathrm{B}\right) \operatorname{or}\left(\operatorname{Max}_{\mathrm{i}} \mathrm{f}_{\mathrm{ij}}^{\mathrm{U}} \mid \mathrm{j} \in \mathrm{C}\right)\right\}$

$\mathrm{B}$ is a set of positive criteria and $\mathrm{C}$ is a set of negative criteria.

Step 3: Calculate values of $\left\lceil S_{i}^{\mathrm{L}} S_{\mathrm{i}}^{\mathrm{U}}\right\rceil,\left\lceil\mathrm{R}_{\mathrm{i}}^{\mathrm{L}} \mathrm{R}_{\mathrm{i}}^{\mathrm{U}}\right\rceil$ 
$S_{i}^{L}=\sum_{j \in B} W_{j}^{L}\left(\frac{f_{j}^{*}-f_{i j}^{U}}{f_{j}^{*}-f_{j}^{-}}\right)+\sum_{j \in B} W_{j}^{L}\left(\frac{f_{i j}^{L}-f_{j}^{*}}{f_{j}^{-}-f_{j}^{*}}\right)$

$S_{i}^{U}=\sum_{j \in B} W_{j}^{U}\left(\frac{f_{j}^{*}-f_{i j}^{L}}{f_{j}^{*}-f_{j}^{-}}\right)+\sum_{j \in B} W_{j}^{U}\left(\frac{f_{i j}^{U}-f_{j}^{*}}{f_{j}^{-}-f_{j}^{*}}\right)$

$R_{i}^{L}=\max _{j}\left\{\begin{array}{l}W_{j}^{L} \frac{f_{j}^{*}-f_{i j}^{U}}{f_{j}^{*}-f_{j}^{-}} \mid j \in B \\ W_{j}^{L} \frac{f_{i j}^{L}-f_{j}^{*}}{f_{j}^{-}-f_{j}^{*}} \mid j \in C\end{array}\right.$

$R_{i}^{U}=\max _{j}\left\{\begin{array}{l}W_{j}^{U} \frac{f_{j}^{*}-f_{i j}^{L}}{f_{j}^{*}-f_{j}^{-}} \mid j \in B \\ W_{j}^{U} \frac{f_{i j}^{U}-f_{j}^{*}}{f_{j}^{-}-f_{j}^{*}} \mid j \in C\end{array}\right.$

Where $\mathrm{W}_{\mathrm{j}}^{\mathrm{U}}$ is lower limit and $\mathrm{W}_{\mathrm{j}}^{\mathrm{U}}$ is upper limit of each criterion's weight.

Step 4: Calculate values of $\left\lceil Q_{\mathrm{i}}^{\mathrm{L}} \mathrm{Q}_{\mathrm{i}}^{\mathrm{U}}\right\rceil$

$\mathrm{Q}_{\mathrm{i}}^{\mathrm{L}}=v\left(\frac{\mathrm{S}_{\mathrm{i}}^{\mathrm{L}}-\mathrm{S}^{*}}{\mathrm{~S}^{-}-\mathrm{S}^{*}}\right)+(1-v)\left(\frac{\mathrm{R}_{\mathrm{i}}^{\mathrm{L}}-\mathrm{R}^{*}}{\mathrm{R}^{-}-\mathrm{R}^{*}}\right)$

$\mathrm{Q}_{\mathrm{i}}^{\mathrm{U}}=v\left(\frac{\mathrm{S}_{\mathrm{i}}^{\mathrm{U}}-\mathrm{S}^{*}}{\mathrm{~S}^{-}-\mathrm{S}^{*}}\right)+(1-v)\left(\frac{\mathrm{R}_{\mathrm{i}}^{\mathrm{U}}-\mathrm{R}^{*}}{\mathrm{R}^{-}-\mathrm{R}^{*}}\right)$

$\mathrm{S}^{*}=\operatorname{Min}_{\mathrm{i}} \mathrm{S}_{\mathrm{i}}^{\mathrm{L}} \cdot \mathrm{S}^{-}=\operatorname{Max}_{\mathrm{i}}^{\mathrm{U}} \cdot \mathrm{R}^{*}=\operatorname{Min}_{\mathrm{i}} \mathrm{R}_{\mathrm{i}}^{\mathrm{L}} \cdot \mathrm{R}^{*}=\operatorname{Max}_{\mathrm{i}} \mathrm{R}_{\mathrm{i}}^{\mathrm{U}}$

$\mathrm{Q}$ is a cumulative index. in addition, $\mathrm{v}$ indicates the weight of the maximum criterion policy and is shown a Shown as $v \in[0.1]$ : usually $v=\frac{0}{5}$

Step 5: Ranking choices according to S, R and Q.

Since the Gray Vikor method suggests the interval weights for the choices of the research, the weight of the choices, similar to the Vikor method, cannot be easily ranked according to the $\mathrm{Q}$ index. To rank the interval weights, there are several ways that are described below.

$\mathrm{A}=\left[\mathrm{a}_{1} \cdot \mathrm{a}_{2}\right] ; \mathrm{B}\left[\mathrm{b}_{1} \cdot \mathrm{b}_{2}\right]$

$C=\left[c_{1} \cdot c_{2}\right]=A-B=\left[a_{1}-b_{2} \cdot a_{2}-b_{1}\right]$

IF $\frac{\left|c_{1}\right|}{c_{2}-c_{1}}<\frac{\left|c_{2}\right|}{c_{2}-c_{1}} \rightarrow$ Then A $>$ B

IF $\frac{\left|c_{1}\right|}{c_{2}-c_{1}}<\frac{\left|c_{2}\right|}{c_{2}-c_{1}} \rightarrow$ Then $A \leq B$ 


\section{Research Findings}

\section{Meta-synthesis and Delphi findings}

In this section, by searching in the databases of scientific and research journals and reputable foreign journals, an attempt was made to select related researches in the first step and then, based on the analytical processes of this section, to identify and determine the components and propositions related to the research topic. The time period for analyzing similar research was 2017 to 2020 AD. In other words, to find similar articles and research and using international and domestic research databases and references, research related to the research goal were identified.

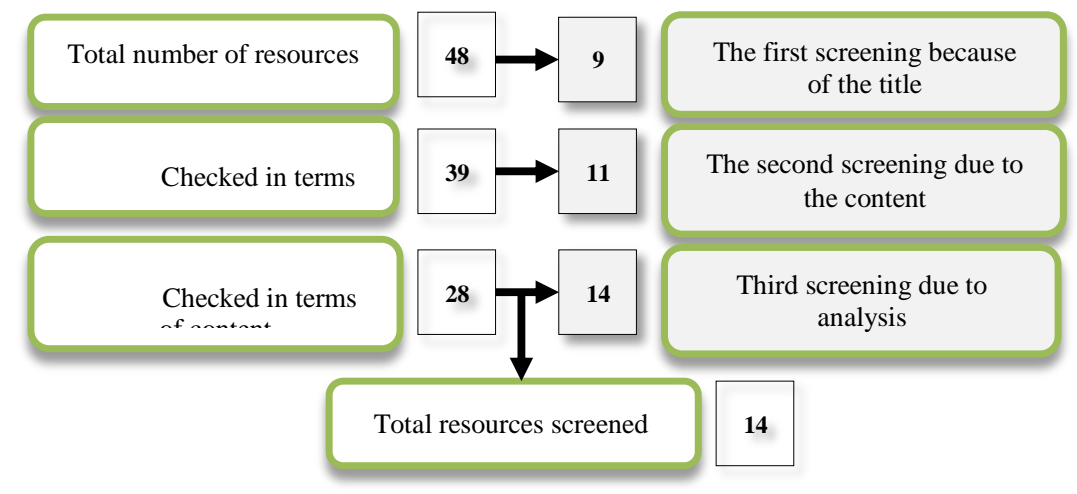

Figure 1. Screening of initial research

As shown in Figure (1), all of the primary sources identified are 48. After several stages of the screening process in terms of content, title and analysis, finally, 14 content-relevant research, title and analytical processes are considered were chosen. At this stage, concepts should be segregated based on components and propositions based on the Attrid-Sterling (2001) method, to determine the capacity of auditors' mindfulness under social conformity pressures in the form of scorecards. In fact, through the criterion of economic evaluation based on 10 criteria of research objectives, the logic of research method, research design, sampling, data collection, reflectivity, the accuracy of analysis, theoretical and transparent expression of findings and research value in section A) to determine the components of social compliance and in section B) attempts are made to determine the propositions of the capacities of the mind against pressure. 
Choosing Influential Dimension of Mindfulness of Auditors'...

\section{A) Identification of social conformity propositions (N)}

In this section, according to the explanations given, the statements of social conformity with the symbol $(\mathrm{N})$ are identified. Table (1) evaluates how to evaluate propositions based on a 50-point index in the form of scores from 1 to 5 based on the 10 criteria described.

Table 1. the process of critical analysis of screened research

\begin{tabular}{|c|c|c|c|c|c|c|c|c|c|c|c|c|}
\hline 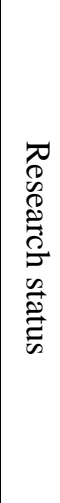 & $\begin{array}{l}\text { Critical } \\
\text { evaluation } \\
\text { criteria }\end{array}$ & 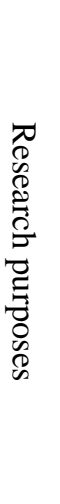 & 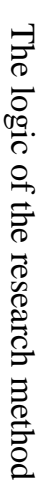 & 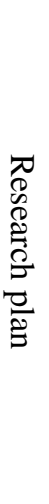 & 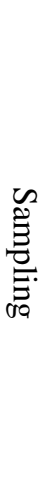 & 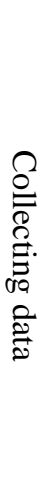 & 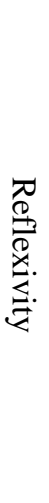 & 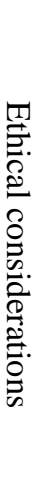 & 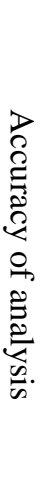 & 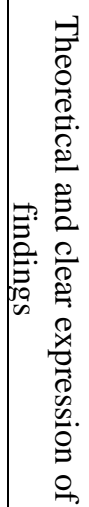 & 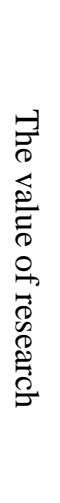 & $\stackrel{\overrightarrow{0}}{\hat{\theta}}$ \\
\hline \multirow{8}{*}{ 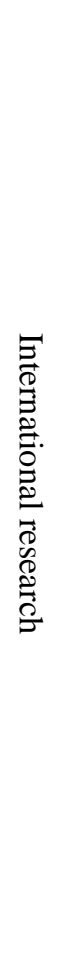 } & $\begin{array}{l}\text { Naeem } \\
(2020)\end{array}$ & 2 & 2 & 3 & 4 & 3 & 3 & 3 & 3 & 3 & 4 & 21 \\
\hline & $\begin{array}{c}\text { Robertson } \\
\text { \& Samy } \\
(2019)\end{array}$ & 4 & 4 & 4 & 4 & 4 & 4 & 4 & 3 & 4 & 4 & 39 \\
\hline & $\begin{array}{c}\text { Preda \& } \\
\text { Kumar } \\
(22019) \\
\end{array}$ & 3 & 3 & 3 & 3 & 3 & 4 & 3 & 3 & 3 & 5 & 33 \\
\hline & $\begin{array}{c}\text { Singh \& } \\
\text { Kumar } \\
(2019)\end{array}$ & 3 & 4 & 4 & 4 & 3 & 4 & 4 & 4 & 3 & 4 & 37 \\
\hline & $\begin{array}{c}\text { Pao et al } \\
\text { (2018) }\end{array}$ & 4 & 4 & 3 & 4 & 2 & 3 & 4 & 4 & 4 & 4 & 36 \\
\hline & $\begin{array}{l}\text { Mauksch } \\
\text { et al } \\
(2017)\end{array}$ & 4 & 3 & 3 & 4 & 3 & 3 & 3 & 4 & 4 & 4 & 31 \\
\hline & $\begin{array}{l}\text { Zhang et } \\
\text { al (2015) }\end{array}$ & 2 & 2 & 3 & 4 & 3 & 3 & 3 & $r$ & 3 & 4 & 21 \\
\hline & $\begin{array}{l}\text { Brandau } \\
\text { et al }\end{array}$ & 4 & 5 & 5 & 3 & 4 & 3 & 3 & 3 & 4 & 4 & 38 \\
\hline
\end{tabular}




\begin{tabular}{|c|c|c|c|c|c|c|c|c|c|c|c|c|}
\hline & (2013) & & & & & & & & & & & \\
\hline & $\begin{array}{c}\text { Nasution } \\
\& \\
\text { Ostermark } \\
(2012)\end{array}$ & 3 & 4 & 5 & 4 & 3 & 3 & 2 & 3 & 3 & 4 & 30 \\
\hline \multirow{5}{*}{ 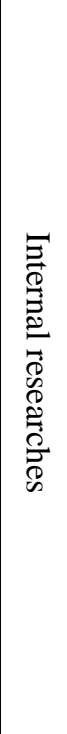 } & $\begin{array}{c}\text { Golshayan } \\
\text { et al } \\
(2016) \\
\end{array}$ & 3 & 3 & 3 & 3 & 4 & 3 & 3 & 3 & 4 & 4 & 33 \\
\hline & $\begin{array}{c}\text { Jafari } \\
\text { Nasab } \\
\text { Kermani } \\
\text { et al } \\
(2019) \\
\end{array}$ & 3 & 3 & 3 & 3 & 4 & 3 & 3 & 4 & 4 & 3 & 33 \\
\hline & $\begin{array}{c}\text { Yarahmad } \\
\text { i (2018) }\end{array}$ & 3 & 3 & 3 & 4 & 3 & 4 & 4 & 4 & 3 & 4 & 35 \\
\hline & $\begin{array}{l}\text { Bonabi } \\
\text { Ghadim } \\
(2017)\end{array}$ & 4 & 5 & 4 & 4 & 3 & 4 & 4 & 3 & 5 & 4 & 39 \\
\hline & $\begin{array}{c}\text { Sepasi \& } \\
\text { Rezayat ( } \\
\text { 2015) }\end{array}$ & 2 & 2 & 2 & 1 & 2 & 2 & 2 & 3 & 3 & 3 & 23 \\
\hline
\end{tabular}

The scores presented based on the fashion index showed three Naeem studies (2020); Zhang et al (2015) and Sepasi and Rezayat (2015) were excluded because they received less than 30 out of 50 points and according to the guidelines of the adequacy score of this analysis, the researches that have a score of 30 and above are approved. And for this reason, they were excluded from the investigation and then, using the Trade-Sterling method (2001), the propositions of social conformity of research are extracted. Accordingly, the following scoring method is used to determine the propositions of pressures due to social compliance. Based on this method, all sub-criteria extracted from the text of approved articles are written in the table column and then, in the row of each table, the names of the researchers of the approved research are given. Based on each researcher's use of the sub-criteria written in the table column, the symbol " $\nabla "$ is inserted, then the scores of each $\nabla$ in the sub-criteria column are added together and the scores above the average of the research are selected as research components. 
Choosing Influential Dimension of Mindfulness of Auditors'...

Table 2. The process of determining the main research propositions

\begin{tabular}{|c|c|c|c|c|c|c|c|c|}
\hline 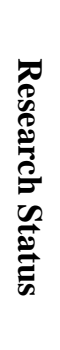 & Researchers & 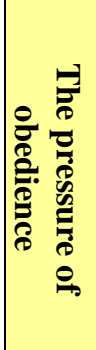 & 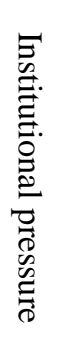 & 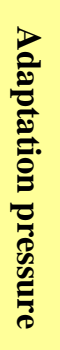 & 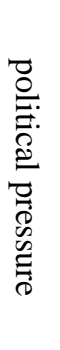 & 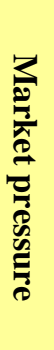 & 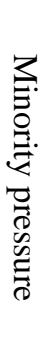 & 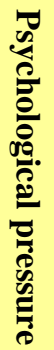 \\
\hline \multirow{7}{*}{ 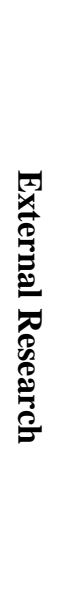 } & Robertson \& Samy (2019) & - & - & $\checkmark$ & $\checkmark$ & - & - & $\checkmark$ \\
\hline & Preda \& Kumar (22019) & - & $\checkmark$ & - & - & $\checkmark$ & $\checkmark$ & - \\
\hline & Singh \& Kumar (2019) & - & - & $\checkmark$ & $\checkmark$ & $\checkmark$ & - & - \\
\hline & Pao et al (2018) & - & $\checkmark$ & - & - & $\checkmark$ & - & $\checkmark$ \\
\hline & Mauksch et al (2017) & $\checkmark$ & $\checkmark$ & $\checkmark$ & $\checkmark$ & $\checkmark$ & - & - \\
\hline & Brandau et al (2013) & $\checkmark$ & - & $\checkmark$ & - & - & - & - \\
\hline & Nasution \& Ostermark (2012) & $\checkmark$ & - & - & - & - & - & $\checkmark$ \\
\hline \multirow{4}{*}{ 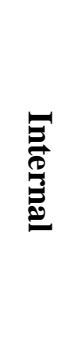 } & Golshaeian et al (2016) & $\checkmark$ & $\checkmark$ & - & $\checkmark$ & $\checkmark$ & - & - \\
\hline & Jafari Nasab Kermani et al (2019) & $\checkmark$ & - & $\checkmark$ & - & $\checkmark$ & $\checkmark$ & $\checkmark$ \\
\hline & Yarahmadi (2018) & $\checkmark$ & - & $\checkmark$ & - & $\checkmark$ & & $\checkmark$ \\
\hline & Banaii Ghadim (2017) & $\checkmark$ & - & $\checkmark$ & - & - & - & $\checkmark$ \\
\hline \multicolumn{2}{|r|}{ Total } & 7 & 4 & 7 & 4 & 7 & 2 & 6 \\
\hline
\end{tabular}

Based on this analysis, 4 propositions of obedience pressure were identified; Compliance pressure; Market pressure and psychological pressure are the most common and therefore in this study are examined as the main criteria of the supply chain. In this section, after analyzing the theoretical foundations of the approved research, each of the identified propositions is defined according to Table (3). 
Table 3. Supply Chain Flexibility Statements

\begin{tabular}{|c|c|}
\hline $\begin{array}{c}\text { Compon } \\
\text { ents }\end{array}$ & Description of each component \\
\hline 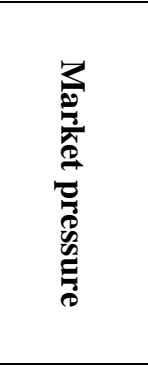 & $\begin{array}{l}\text { One of the pressures of social conformity; pressure is due to market inequalities, } \\
\text { where auditors with low market share are forced to comply with the demands of } \\
\text { influencers, intermediaries and owners. Because to gain more market share, } \\
\text { regardless of specialized capacities and professional capabilities, one must look for } \\
\text { external variables such as the reputation of the owners; Disregard for the } \\
\text { philosophy of the auditing profession; Influence of intermediaries in audit } \\
\text { negotiations and ...., to achieve market share on this basis, such harmonized } \\
\text { pressures due to the power of a group of auditing firms can affect the independence } \\
\text { of auditors. }\end{array}$ \\
\hline 窟 & $\begin{array}{l}\text { Adaptation pressure refers to pressure from co-workers or peers. Based on the } \\
\text { pressure of adaptation, a person is under pressure to act in accordance with the } \\
\text { beliefs, attitudes and actions of their colleagues and peers. Standards developers } \\
\text { have made extensive efforts to ensure that auditors are independent of the client. } \\
\text { An individual auditor may experience a conflict of interest not only in the content } \\
\text { of the auditor's breach of independence, but a conflict of interest may also arise } \\
\text { from a situation in which the auditor assumes that his or her personal interests do } \\
\text { not align with those of other auditors or the audit firm as a whole. }\end{array}$ \\
\hline 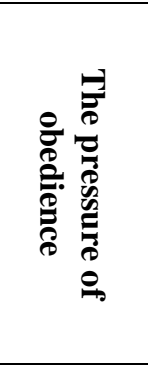 & $\begin{array}{l}\text { The pressure of obedience is exerted by a person with more power in the higher } \\
\text { organizational hierarchy. Individual behavior with more authority and power can } \\
\text { influence the behavior of others through their own views and give them an } \\
\text { intellectual framework. These people may be indifferent to the execution of such } \\
\text { actions as prescribed by a superior or authority; Even if these actions contradict } \\
\text { their individual beliefs and principles. Given that in an auditing firm, managers and } \\
\text { partners are superiors or people in power, the existence of such pressures is not far- } \\
\text { fetched. In other words, the auditor will obey the orders and suggestions of his } \\
\text { superior not only to avoid punishment or reward but also to maintain his position. }\end{array}$ \\
\hline 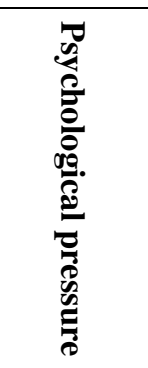 & $\begin{array}{l}\text { Under the influence of this pressure, auditors do not have the necessary capabilities } \\
\text { to meet the demands and interests of owners and intermediaries. The existence of } \\
\text { such pressures is directly related to the characteristics of the auditor, a point that } \\
\text { can weaken their judgments under the influence of such pressures and reinforce the } \\
\text { emergence of behavioral opportunities in auditors. It should be noted that the } \\
\text { results of some studies have shown that the presence of the mentioned pressure in } \\
\text { the audit increases the attention to the cost of personal reputation and leads to } \\
\text { motivating auditors to perform activities that can jeopardize the effectiveness of the } \\
\text { audit process. }\end{array}$ \\
\hline
\end{tabular}

\section{B) Identify the components of auditors' mindfulness (M)}

As in the above steps and following the critical evaluation method in this section, the capacities of the auditors' minds are determined. In this section, according to the explanations given, the components of auditors' mindfulness with the symbol (M) are identified. Table (4) evaluates how to evaluate components based on a 50-point index in the form of scores from 1 to 5 based on the 10 criteria described. 
Choosing Influential Dimension of Mindfulness of Auditors'...

Table 4. The process of critical analysis of screened research

\begin{tabular}{|c|c|c|c|c|c|c|c|c|c|c|c|c|}
\hline 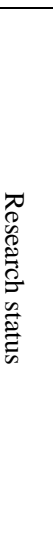 & $\begin{array}{r}\begin{array}{r}\text { Critical } \\
\text { evaluation } \\
\text { criteria }\end{array} \\
/\end{array}$ & 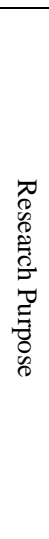 & 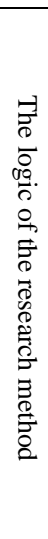 & 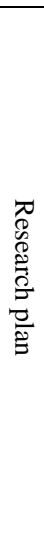 & 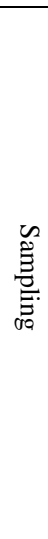 & 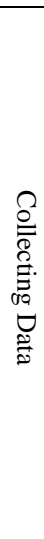 & $\begin{array}{l}\underset{0}{0} \\
\stackrel{0}{0} \\
\stackrel{0}{0} \\
\stackrel{0}{0} \\
0\end{array}$ & 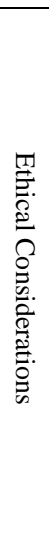 & 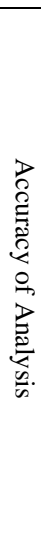 & 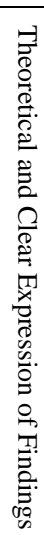 & 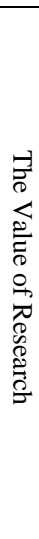 & $\stackrel{\overrightarrow{0}}{\stackrel{0}{D}}$ \\
\hline & $\begin{array}{l}\text { Bucaro } \\
(2019)\end{array}$ & 3 & 4 & 3 & 3 & 4 & 3 & 4 & 4 & 4 & 4 & 36 \\
\hline & $\begin{array}{l}\text { Suyono } \\
\text { and } \\
\text { Farooque } \\
(2019)\end{array}$ & 4 & 5 & 4 & 4 & 5 & 4 & $\Delta$ & 4 & 4 & 5 & 44 \\
\hline & $\begin{array}{l}\text { Mubako } \\
\text { and } \\
\text { Donnell } \\
(2018)\end{array}$ & 3 & 2 & 3 & 2 & 3 & 2 & 3 & 2 & 3 & 3 & 26 \\
\hline & $\begin{array}{c}\text { Kirmizia } \\
\text { et al } \\
(2015)\end{array}$ & 4 & 5 & 5 & 3 & 4 & 3 & 3 & 3 & 4 & 4 & 38 \\
\hline & $\begin{array}{l}\text { Griffith et } \\
\text { al (2014) }\end{array}$ & 4 & 4 & 4 & 3 & 4 & 3 & 3 & 4 & 4 & 4 & 37 \\
\hline & $\begin{array}{l}\text { Knechel et } \\
\text { al (2013) }\end{array}$ & 3 & 4 & 3 & 3 & 3 & 3 & 4 & 3 & 3 & 3 & 32 \\
\hline & $\begin{array}{l}\text { Grossman } \\
\text { \& Welker } \\
(2011)\end{array}$ & 2 & 3 & 2 & 2 & 2 & 2 & 3 & 2 & 2 & 2 & 22 \\
\hline \multirow{5}{*}{ 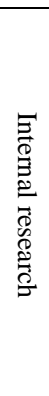 } & $\begin{array}{l}\text { Ebrahimi } \\
\text { et al } \\
(2020)\end{array}$ & 4 & 3 & 4 & 3 & 4 & 4 & 4 & 4 & 4 & 4 & 38 \\
\hline & $\begin{array}{l}\text { Shafati et } \\
\text { al (2020) }\end{array}$ & 3 & 3 & 3 & 3 & 2 & 3 & 4 & 3 & 4 & 4 & 32 \\
\hline & $\begin{array}{c}\text { Hosseini et } \\
\text { al (2020) }\end{array}$ & 3 & 3 & 3 & 4 & 5 & 4 & 4 & 4 & 4 & 4 & 36 \\
\hline & $\begin{array}{c}\text { Javidi et al } \\
\text { (2018) }\end{array}$ & 3 & 4 & 4 & 4 & 4 & 4 & 3 & 4 & 5 & 5 & 40 \\
\hline & $\begin{array}{c}\text { Abed } \\
\text { Nazari et } \\
\text { al ( 2018) }\end{array}$ & 3 & 2 & 2 & 2 & 2 & 3 & 4 & 3 & 3 & 3 & 27 \\
\hline
\end{tabular}

The scores presented based on the mode index showed that out of a total of 12 initial kinds of research, three types of research of Mobako and Donnell (2018); Grossman and Volker (2011) and Abednazari et al (2016) considering that out of 50 points, they received less than 30 and in accordance with the 
guidelines for the adequacy of the score of this analysis, the studies that are approved with a score of 30 or higher are eliminated, and for this reason, they were excluded from the investigation. Then, using the Trade-Sterling method (2001), research propositions are extracted. Accordingly, the following scoring method is used to determine the components of auditors' mindfulness capacity. Based on this method, all sub-criteria extracted from the text of approved articles are written in the table column and then the names of the approved research researchers are listed in the row of each table. Based on each researcher's use of the sub-criteria written in the table column, the symbol " $\square$ " is inserted, then the scores of each $\nabla$ are added together in the sub-criteria column, and scores above the average of the conducted research are selected as research components.

Table 5. The process of determining the main components of research

\begin{tabular}{|c|c|c|c|c|c|c|c|}
\hline Status & Researchers & 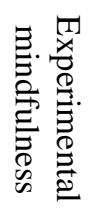 & 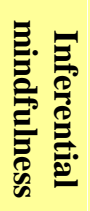 & 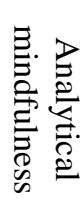 & 总 & 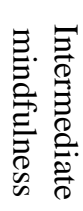 & 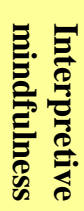 \\
\hline \multirow{5}{*}{$\begin{array}{c}\text { International } \\
\text { Researches }\end{array}$} & Bucaro (2019) & - & - & - & $\checkmark$ & - & - \\
\hline & $\begin{array}{c}\text { Suyono and Farooque } \\
(2019)\end{array}$ & - & $\checkmark$ & $\checkmark$ & - & $\checkmark$ & - \\
\hline & Kirmizia et al (2015) & $\checkmark$ & - & - & $\checkmark$ & $\checkmark$ & - \\
\hline & Griffith et al (2014) & - & $\checkmark$ & - & - & - & $\checkmark$ \\
\hline & Knechel et al (2013) & - & $\checkmark$ & $\checkmark$ & $\checkmark$ & - & $\checkmark$ \\
\hline \multirow{4}{*}{ Internal Researches } & Ebrahimi et al (2020) & $\checkmark$ & - & - & $\checkmark$ & - & $\checkmark$ \\
\hline & Shafaati et al (2020) & - & $\checkmark$ & $\checkmark$ & - & $\checkmark$ & $\checkmark$ \\
\hline & Hosseini et al (2020) & - & $\checkmark$ & - & $\checkmark$ & - & $\checkmark$ \\
\hline & Javidi et al (2018) & - & $\checkmark$ & - & $\checkmark$ & - & $\checkmark$ \\
\hline \multicolumn{2}{|c|}{ Total } & 2 & 6 & 3 & 6 & 3 & 5 \\
\hline
\end{tabular}

Based on this analysis, three components of inferential mindfulness were identified; Intuitive mindfulness and interpretive mindfulness are the most common. In this section, after analyzing the theoretical foundations of the approved research, each of the identified components has been defined according to Table (6). 
Choosing Influential Dimension of Mindfulness of Auditors'...

Table 6. Components of Auditors' Mindfulness

\begin{tabular}{|c|c|}
\hline $\begin{array}{c}\text { Components of Auditors' } \\
\text { Mindfulness }\end{array}$ & Definitions \\
\hline 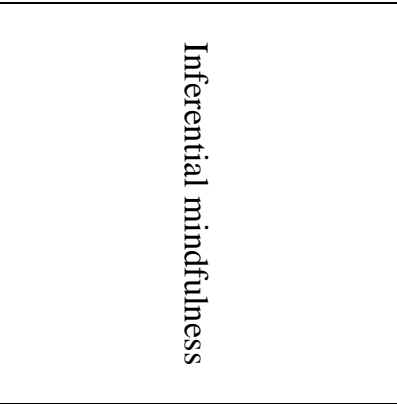 & $\begin{array}{l}\text { Inferential mindfulness refers to the ability to analyze the } \\
\text { evidence and performance facts of companies in proportion } \\
\text { to the level of the capital market, in such a way that an } \\
\text { auditor, with this kind of attitude, processes environmental } \\
\text { information and participates in the capital market to } \\
\text { shareholders, investors and the government, in this way, } \\
\text { relying on Levy's point of view, to achieve a proper } \\
\text { understanding and decision-making to solve a problem } \\
\text { based on accurate reasons and credible evidence, (Shafaati } \\
\text { et al, 2020). }\end{array}$ \\
\hline 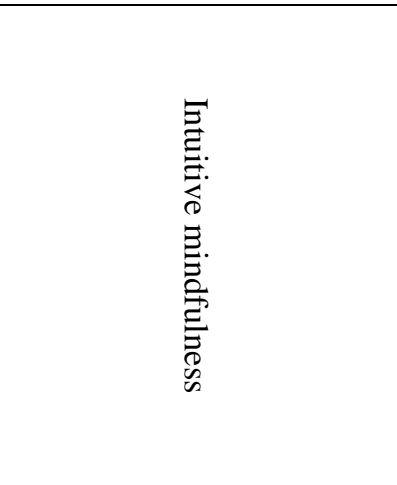 & $\begin{array}{l}\text { As Butler and Halpern (2012) stated, this level of } \\
\text { mindfulness in auditors refers to the auditors' mental, } \\
\text { perceptual, and cognitive skills in analyzing corporate } \\
\text { financial performance. In fact, intuitive mindfulness is } \\
\text { based on the insights and inspirations of the individual that } \\
\text { auditors sometimes use their intuitive power and decision- } \\
\text { making power to control the accounts and performance of } \\
\text { the company. In other words, this level of mindfulness, } \\
\text { although it may not be a scientific basis and based on } \\
\text { specific evidence, because it is based on the experience and } \\
\text { expertise of the auditor, they can use this judgment in their } \\
\text { reporting with a brief look at the totality of accounts. }\end{array}$ \\
\hline 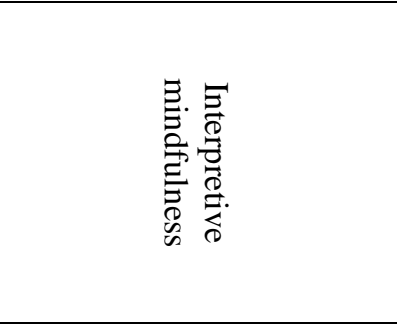 & $\begin{array}{l}\text { Interpretive mindfulness refers to the level of interpretive } \\
\text { and inferential capabilities to establish a structure of } \\
\text { reasoning between facts and misleading actions of } \\
\text { companies to better prove the behavioral and functional } \\
\text { reasons of companies. At this level of mindfulness, auditors } \\
\text { who have this attitude try to discover a more inferential } \\
\text { understanding of companies' realities through abstract } \\
\text { techniques (Duron et al, 2006). }\end{array}$ \\
\hline
\end{tabular}

In this section, to determine the components of the research in the form of research variables, first the identified components and propositions of the research in the form of a 7-point Likert scale checklist and then among 13 elites as panel members selected through homogeneous sampling was distributed, to determine whether their opinion on the alignment of the nature of research variables with the identified components and propositions is theoretically sufficient or not. 
Iranian Journal of Finance, 2022, Vol. 6, No. 2 (Soleymani, S. M.)

Table 7. The process of the first and second steps of Delphi analysis

\begin{tabular}{|c|c|c|c|c|c|c|c|}
\hline \multirow{2}{*}{$\begin{array}{c}\text { Component } \\
\text { s / } \\
\text { Proposition } \\
\text { s }\end{array}$} & \multirow{2}{*}{$\begin{array}{l}\text { Assessment } \\
\text { criteria }\end{array}$} & \multirow{2}{*}{$\begin{array}{c}\text { Symbol } \\
\text { s }\end{array}$} & \multicolumn{2}{|c|}{$\begin{array}{l}\text { The first round of } \\
\text { Delphi }\end{array}$} & \multicolumn{2}{|c|}{$\begin{array}{c}\text { The second round } \\
\text { of Delphi }\end{array}$} & \multirow[b]{2}{*}{ Result } \\
\hline & & & $\begin{array}{c}\text { Mea } \\
\mathrm{n}\end{array}$ & $\begin{array}{l}\text { Coefficien } \\
\text { t of } \\
\text { agreement }\end{array}$ & $\begin{array}{c}\text { Mea } \\
\mathrm{n}\end{array}$ & $\begin{array}{l}\text { Coefficien } \\
\text { t of } \\
\text { agreement }\end{array}$ & \\
\hline \multirow{4}{*}{$\begin{array}{l}\text { Proposition } \\
\text { s of social } \\
\text { conformity }\end{array}$} & $\begin{array}{l}\text { Market } \\
\text { pressure }\end{array}$ & N1 & 5.20 & 0.82 & 5.30 & 0.85 & $\begin{array}{c}\text { Confir } \\
\mathrm{m}\end{array}$ \\
\hline & $\begin{array}{l}\text { Adaptation } \\
\text { pressure }\end{array}$ & N2 & 5.20 & 0.80 & 5.20 & 0.80 & $\begin{array}{c}\text { Confir } \\
\mathrm{m}\end{array}$ \\
\hline & $\begin{array}{l}\text { The pressure } \\
\text { of obedience }\end{array}$ & N3 & 6 & 0.90 & 5.20 & 0.80 & $\begin{array}{c}\text { Confir } \\
\mathrm{m}\end{array}$ \\
\hline & $\begin{array}{l}\text { Psychologica } \\
1 \text { pressure }\end{array}$ & N4 & 5.20 & 0.82 & 6 & 0.90 & $\begin{array}{c}\text { Confir } \\
\mathrm{m}\end{array}$ \\
\hline \multirow{3}{*}{$\begin{array}{l}\text { Component } \\
\text { s of } \\
\text { Auditors' } \\
\text { Mindfulnes } \\
\text { s }\end{array}$} & $\begin{array}{l}\text { Inferential } \\
\text { mindfulness }\end{array}$ & M1 & 5.10 & 0.75 & 5.10 & 0.75 & $\begin{array}{c}\text { Confir } \\
\mathrm{m}\end{array}$ \\
\hline & $\begin{array}{c}\text { Intuitive } \\
\text { mindfulness }\end{array}$ & M2 & 5.30 & 0.85 & 6 & 0.90 & $\begin{array}{c}\text { Confir } \\
\mathrm{m}\end{array}$ \\
\hline & $\begin{array}{l}\text { Interpretive } \\
\text { mindfulness }\end{array}$ & M3 & 5.40 & 0.80 & 5.30 & 0.85 & $\begin{array}{c}\text { Confir } \\
\mathrm{m}\end{array}$ \\
\hline
\end{tabular}

As can be seen, all the identified components and propositions about the research variables were confirmed during the two stages of Delphi analysis.

\section{Rough analysis}

After determining the codes related to the components and propositions of the research, after forming the propositions and components of the research, it is time to calculate the weight of the research criteria using the gray hierarchical analysis process. For this purpose, after forming the pairwise comparison matrix of the problem, the opinions of experts were collected. In the next step, the degree of incompatibility of each pairwise comparison matrix was determined. If the incompatibility of the pairwise comparison questionnaires is standard (less than 0.1), the next step can be started, otherwise, the pairwise comparison questionnaires will be returned to the experts for review. After confirming the compatibility of the pairwise comparison questionnaires using Rough theory (Equations 1 to 6), the experts' opinion was converted to distance numbers. Finally, the criteria were obtained using equations of 8 to 10 weights. Table (8) shows the results obtained from the calculations of the gray hierarchical analysis process. 
Choosing Influential Dimension of Mindfulness of Auditors'...

Table 8. Results of the Gray Hierarchical Analysis Process

\begin{tabular}{|c|c|c|c|c|c|c|c|}
\hline \multirow[b]{2}{*}{ Purposes } & \multicolumn{2}{|c|}{ Weight criteria } & \multirow[b]{2}{*}{ Elements } & \multicolumn{2}{|c|}{ Weight of elements } & \multicolumn{2}{|c|}{$\begin{array}{l}\text { The final weight } \\
\text { of the elements }\end{array}$} \\
\hline & $\begin{array}{c}\text { Low } \\
\text { limit } \\
(\mathrm{L}) \\
\end{array}$ & $\begin{array}{c}\text { Upper } \\
\text { limit } \\
(\mathrm{U}) \\
\end{array}$ & & $\begin{array}{c}\text { Low } \\
\text { limit } \\
(\mathrm{L}) \\
\end{array}$ & $\begin{array}{c}\text { Upper } \\
\text { limit (U) }\end{array}$ & $\begin{array}{c}\text { Low } \\
\text { limit } \\
(\mathrm{L}) \\
\end{array}$ & $\begin{array}{c}\text { Upper } \\
\text { limit } \\
(\mathrm{U}) \\
\end{array}$ \\
\hline \multirow{4}{*}{$\begin{array}{l}\text { Proposals of } \\
\text { social } \\
\text { conformity }\end{array}$} & \multirow{4}{*}{0.73} & \multirow{4}{*}{0.86} & $\begin{array}{l}\text { Market } \\
\text { pressure }\end{array}$ & 0.331 & 0.382 & 0.277 & 0.382 \\
\hline & & & $\begin{array}{l}\text { Adaptation } \\
\text { pressure }\end{array}$ & 0.209 & 0.302 & 0.192 & 0.302 \\
\hline & & & $\begin{array}{l}\text { The pressure } \\
\text { of obedience }\end{array}$ & 0.340 & 0.418 & 0.298 & 0.418 \\
\hline & & & $\begin{array}{l}\text { Psychological } \\
\text { pressure }\end{array}$ & 0.161 & 0.280 & 0.144 & 0.280 \\
\hline \multirow{3}{*}{$\begin{array}{l}\text { Components } \\
\text { of Auditors' } \\
\text { Mindfulness }\end{array}$} & \multirow{3}{*}{0.61} & \multirow{3}{*}{0.70} & $\begin{array}{c}\text { Inferential } \\
\text { mindfulness }\end{array}$ & 0.139 & 0.289 & $1100 /$ & 0.290 \\
\hline & & & $\begin{array}{c}\text { Intuitive } \\
\text { mindfulness }\end{array}$ & 0.156 & 0.229 & 0.119 & 0.224 \\
\hline & & & $\begin{array}{l}\text { Interpretive } \\
\text { mindfulness }\end{array}$ & 0.718 & 0.935 & 0.697 & 0.935 \\
\hline
\end{tabular}

According to the final weight of each component and proposition, it is determined that the incompatibility values are below 0.1 , based on which the second step of the rough analysis can be entered. The next step after calculating the weight of the research criteria is to form a problem decision matrix. To form the distance decision matrix, experts' opinions on the status of each of the options in each of the criteria were first collected using the Vicker questionnaire, the results of which are presented in Table (9).

Table 9. Expert opinion on each of the options based on what criteria

\begin{tabular}{|c|c|c|c|c|c|c|}
\hline \multicolumn{7}{|c|}{ We tivs baycion } \\
\hline \multirow{2}{*}{\multicolumn{3}{|c|}{ Components / Propositions }} & $\begin{array}{l}\text { Market } \\
\text { pressure }\end{array}$ & $\begin{array}{l}\text { Adaptation } \\
\text { pressure }\end{array}$ & $\begin{array}{c}\text { The pressure of } \\
\text { obedience }\end{array}$ & $\begin{array}{l}\text { Psychological } \\
\text { pressure }\end{array}$ \\
\hline & & & (N1) & $(\mathrm{N} 2)$ & (N3) & $(\mathrm{N} 4)$ \\
\hline \multicolumn{2}{|l|}{ Inferential mindfulness } & M1 & 4 & 3 & 4 & 3 \\
\hline \multicolumn{2}{|l|}{ Intuitive mindfulness } & M2 & 3 & 5 & 4 & 3 \\
\hline \multicolumn{2}{|l|}{ Interpretive mindfulness } & M3 & 4 & 5 & 4 & 3 \\
\hline \multicolumn{7}{|c|}{ We ins batcioni } \\
\hline \multirow{2}{*}{\multicolumn{2}{|c|}{ Components / Propositions }} & \multicolumn{2}{|c|}{ Market pressure } & $\begin{array}{l}\text { Adaptation } \\
\text { pressure }\end{array}$ & $\begin{array}{l}\text { The pressure } \\
\text { of obedience }\end{array}$ & $\begin{array}{c}\text { Psychological } \\
\text { pressure }\end{array}$ \\
\hline & & & (N1) & $(\mathrm{N} 2)$ & (N3) & $(\mathrm{N} 4)$ \\
\hline Inferential mindfulness & M1 & & 2 & 4 & 5 & 4 \\
\hline Intuitive mindfulness & M2 & & 6 & 5 & 4 & 3 \\
\hline Interpretive mindfulness & M3 & & 3 & 3 & 5 & 4 \\
\hline
\end{tabular}


After distributing and analyzing the experts' opinions about the status of each option in each of the propositions, a decision matrix is formed to analyze the problem. To form a decision-making table, the analysis of the opinions of 19 audit partners with more than 5 years of experience as members of the target community in the quantitative sector must first be converted into interval numbers. Equations 1 to 6 are used to convert score analyses to distance numbers. Table (10) shows the decision matrix of the distances obtained from the rough method:

Table 10. Decision analysis distance analysis matrix

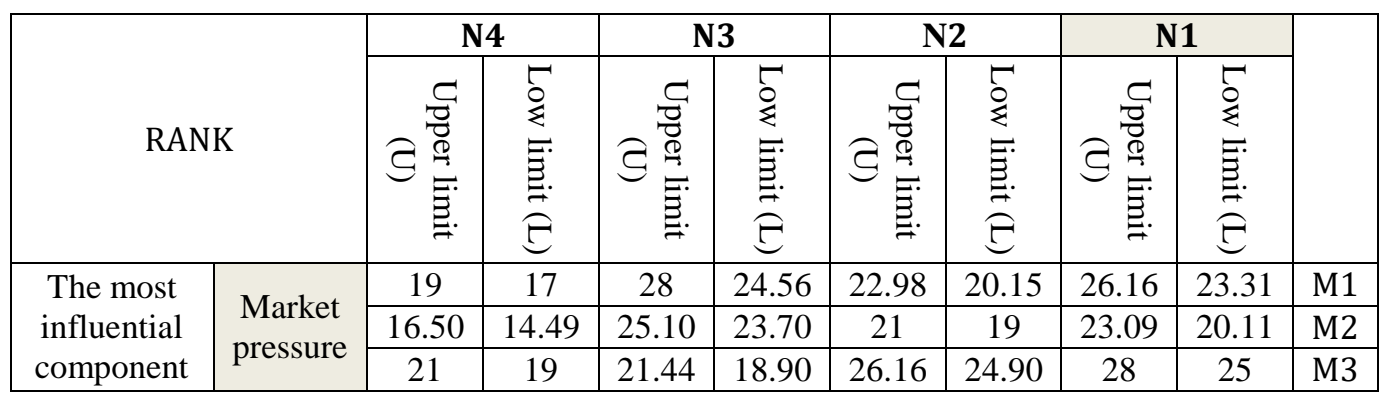

Based on the result of the distance decision matrix, the market pressure (N1) is the most important expression of the pressure due to social compliance. The pressure of obedience (N3) was also found to be another important proposition of the pressure of social cohesion. Then, to analyze Grey Vickor, research options will be examined and evaluated. The first step in the Grey Vickor method after the formation of the decision matrix is to identify the values of positive ideal and $\left(f_{j}^{*}\right)$ negative ideal $\left(f_{j}^{-}\right)$in each of the criteria of the decision matrix. Table (11) shows the results obtained:

Table 11. Determining positive and negative ideals

\begin{tabular}{|c|c|c|c|c|}
\hline & $(\mathrm{N} 1)$ & $(\mathrm{N} 2)$ & $(\mathrm{N} 3)$ & $(\mathrm{N} 4)$ \\
\hline Positive ideal $\left(f_{j}^{*}\right)$ & 29.14 & 26.44 & 27.83 & 21.63 \\
\hline Negative ideal $\left(f_{j}^{-}\right)$ & 16.37 & 17.63 & 17.02 & 20.07 \\
\hline
\end{tabular}

As can be seen, none of the propositions has a higher negative ideal than the positive ideal, and this reflects the effectiveness of all propositions concerning the mindfulness of the auditing profession. However, the results also confirmed that market pressure (N1) and obedience pressure (N3) are more desirable than other propositions, which shows that social compliance pressures in the form of market pressure can affect the performance of auditors. But to understand the most important dimension of mindfulness of judging the 
auditing profession based on market pressures, one must rely on the Grey Vikor method as the last step. That is, based on relations (16) to (19), first, the propositions $S_{i}^{U}, S_{i}^{L}, R_{i}^{U}, R_{i}^{L}$ are calculated, then by specifying the propositions, the main proposition of Vicky Grey, ie Q, is determined from the relations (20) and (21) are used. Table (12) shows the results of the calculations.

Table 12. Analysis of Grey Vikor Method propositions

\begin{tabular}{|c|c|c|c|c|c|c|c|}
\hline $\begin{array}{c}\text { Mindfulness of } \\
\text { professional } \\
\text { auditors }\end{array}$ & Code & $\mathrm{S}_{\mathrm{i}}^{\mathrm{U}}$ & $S_{i}^{L}$ & $\mathrm{R}_{\mathrm{i}}^{\mathrm{U}}$ & $\mathrm{R}_{\mathrm{i}}^{\mathrm{L}}$ & $\mathrm{Q}_{\mathrm{i}}^{\mathrm{U}}$ & $\mathrm{Q}_{\mathrm{i}}^{\mathrm{L}}$ \\
\hline $\begin{array}{c}\text { Inferential } \\
\text { mindfulness }\end{array}$ & M1 & 0.983652 & 1.935570 & 0.227682 & 0.443626 & 0.318264 & 0.552685 \\
\hline $\begin{array}{c}\text { Intuitive } \\
\text { mindfulness }\end{array}$ & M2 & 1.021878 & 2.001920 & 0.357082 & 0.524165 & 0.421879 & 0.673827 \\
\hline $\begin{array}{l}\text { Interpretive } \\
\text { mindfulness }\end{array}$ & M3 & 1.438927 & 2.365281 & 0.382716 & 0.553678 & 0.460201 & 0.702605 \\
\hline \multirow{2}{*}{$\begin{array}{l}\text { Assessment } \\
\text { criteria }\end{array}$} & \multicolumn{3}{|c|}{ Propositions } & $\mathrm{S}^{*}$ & $\mathrm{~S}^{-}$ & $\mathrm{R}^{*}$ & $\mathrm{R}^{-}$ \\
\hline & \multicolumn{3}{|c|}{ The number of propositions } & 0.700286 & 3.172677 & 0.526359 & 1.000 \\
\hline
\end{tabular}

Since proposition Q represents the most important law in rough analysis, is determining the property to modify or improve the components, in this study, based on Table (12), it was determined that $\mathrm{Q}$ is related to interpretive mindfulness (M1). But since according to Ruff Analysis Guidelines, the lowest $\mathrm{Q}$ value determines the center component, so-called inverse Ruff Analysis, it was determined that the lowest component, inferential mindfulness (M1), is the most important dimension of auditors' professional judgment mindfulness based on pressures. It is market-based. In fact, this result shows that when compliance pressures are based on the lack of a balanced market share, the level of interpretive mindfulness is particularly low, which may be due to the weakening of the auditor's identity in the audit market due to lower market share. In this way, it tries to gain a greater share by approaching well-known clients, on the basis of which it can be expected that the auditor's level of awareness and skepticism will be greatly reduced.

\section{Conclusion}

Every capital market for quality sustainability and effective development to dynamically attract liquidity to advance its investment plans requires quality functions of auditors as one of the pillars of monitoring the performance of companies in the competitive market. In fact, the purpose of auditing and evaluating the level of performance of companies in accordance with accepted accounting standards and principles is to provide professional comments to 
improve the decision-making power of stakeholders. One of the conditions for users to rely on the auditor's report and their comments is to ensure that they maintain behavioral and functional independence from external pressures, which seek to protect their interests by influencing auditors, which due to the invisibility of some external relationships, standards are necessary. It cannot play a role in recognizing and evaluating the independence of auditors. However, it is important to know the dimensions of these influences, which are sometimes caused by social pressures and a kind of social cohesion in the auditors 'own community, because by gaining knowledge about the characteristics of such pressures and auditors' reactions. The use of behavioral strategies controlled it to some extent. The purpose of this study was to investigate the most influential dimension of mindfulness of auditors' professional judgment based on pressures based on social conformity. Given that the basis for the existence of propositions of social conformity and components of mindfulness was not created based on previous research, this research-based on meta-synthesis analysis in the first step identified components as analytical basis of research and propositions as reference variables. Based on this, with the help of 13 experts and experts in the field of accounting at the university level, an attempt was made to identify research components and propositions in the form of score forms. In the second part, based on the analysis of the Rough collection, while identifying the most important component of the effective pressure due to collective conformity, the most effective dimension of mindfulness of the auditors' professional judgment was determined to develop functions by reducing the pressure of collective compliance. The effective mindfulness of auditors is audited at the market level. In the first part, based on the result of interpretive ranking, it was found that the existence of pressures due to an imbalance in the distribution of market share, which in this study was referred to as the market pressure component, are the most motivating factors for violating the minds of auditors. Because auditors are likely to try to increase their share of the audit market in the future by approaching more powerful market owners, based on unbalanced auditing market conditions, they are likely to face violations of social identity theories. The subject causes them to make comments in the form of their opinions that are in line with their demands and forget their professional philosophies. This will directly reduce the level of breach of auditors' mindfulness, especially inferential mindfulness, and the auditor will in this situation prioritize his / her operational priority to achieve greater material benefits. On the other hand, when the management structures of the auditing firm also want to gain more market share, structural pressures from partners to retain more reputable owners will cause prioritize the material benefits of auditing over 
philosophical, professional, and professional interests, and motivate auditors to increase interactivity with powerful owners. This leads to a reduction in the quality of audit functions. The result obtained in the first part with Ali and Abazi research (2018); Corresponds to Nauschen and Ostermark (2012) and Kathleen and Van Staden (2015). In the second part, determining the most influential dimension of the level of mindfulness of the auditors' profession that may be affected by compliance pressures and face a functional breach, mindfulness is inferential, which also affects interpretive and intuitive mindfulness. In analyzing the outcome of this section, it should be noted that the level of inferential mindfulness, which may be a function of professional skepticism but precedes it, reflects the auditor's level of reasoning in the face of the evidence presented by employers, where it seeks to submit your statements based on fact-based arguments. Although this insight is important, under market pressures, it will reduce the auditor's performance functions from the point of view of mindfulness and somehow align its mentality with the demands of the influencers, so that while taking advantage of more benefits, at the same time competitive position strengthen yourself in the auditing market. The result of this section with research by Suyano and Farooq (2019); Griffiths et al (2014); Knechel et al (2013); Shafaati et al (2020). Based on the obtained results, it is suggested that training programs by regulatory bodies to increase the level of mindfulness to strengthen professional skepticism should be considered as a training requirement for auditors and strategies for using the paradigm model of mental readiness to increase the quality of audits be focused. It is also suggested that the speed of action and the power of mental decision-making along with the priority of reviewing the evidence of owners as part of the decision-making arguments of auditors in critical and sensitive situations to train auditors to increase the quality of audit to improve decisionmaking power capital markets help. Also recommended that qualified authorities such as the Iranian Official Accountants Community implement plans to control the increased concentration in the audit market. Most audit firms in Iran are small. This issue has led the auditors to compete in the field of offering discounts in the audit fees so it is likely to reduce the quality of audits. Accordingly, providing more effective monitoring mechanisms is necessary. It is also suggested that the regulatory institutions such as Supreme Audit Court train the necessary skills to the auditors to control the stress by holding the training courses and the behavioural workshops. It is recommended that by codifying more comprehensive rules, the amount of work done by the audit firms (the maximum customer acceptance) in a fiscal period is monitored so that a balance can be established in auditing financial statements among the audit firms or the high workload can be prevented. These suggestions can 
allow standardization of auditors' behaviour and help to improve the audit quality of the Firms' financial statements. Finally, it is suggested that by developing the structures of comprehensive audit culture in the long run, the hidden dimensions of auditors 'behavior under potential social pressures be partially controlled to increase the level of reliability and trust in auditors' reports, especially in competitive capital market conditions in advance. Regarding the limitations of the research, it should be noted that since the present subject relies on individual perception, like any other research in the humanities, it faces the relative challenge of measuring the realities of auditors' perceptions. In other words, the checklists designed may not be analytically responsive to all the mental dimensions of the auditors in terms of external pressure. In other words, there may be institutionalized psychological pressures in the auditing profession that, although auditors are involved, there is no coherent understanding of them, and using interview-based analytical processes to solve these problems can lead to greater effectiveness.

\section{Declaration of Conflicting Interests}

The authors declared no potential conflicts of interest concerning the research, authorship and, or publication of this article.

\section{Funding}

The authors received no financial support for the research, authorship and, or publication of this article.

\section{References}

Abednazari., M., Rahnamay Roodroshti., F., Nikoomaram., H., Poorzamani, Z. (2018). Presenting Pattern of Global Management Accounting Based on Critical Thinking. Management Accounting, 11(39), 67-81.

Ali, A., Abazi, D. (2018). Conformity pressure and auditors' judgement: How peers affect one another in audit firms in Sweden? Master Thesis in Business Administration specializing in Auditing and controlling, 15 credits.

Bentley, J, W., Lambert, T, A., Wang, E, Y. (2020). The Effect of Increased Audit Disclosure on Managers' Real Operating Decisions: Evidence from Disclosing Critical Audit Matters, The Accounting Review, https://doi.org/10.2308/tar2017-0486 
Bonabi ghadim., Rahim. (2017). Threats and social pressures towards the independence of the auditor, Auditor's Journal, 84 (2): 104-111.

Brandau, M., Endenich, Ch., Trapp, R., Hoffjan, A. (2013). Institutional drivers of conformity: Evidence for management accounting, International Business Review, 22(2): 466-479. https://doi.org/10.1016/j.ibusrev.2012.07.001

Brink, A, G., Tang, F., Yang, L. (2016). The Impact of Estimate Source and Social Pressure on Auditors' Fair Value Estimate Choices. Behavioral Research in Accounting, 28(2): 29-40. https://doi.org/10.2308/bria-51457

Butler, H., Halpern, A. (2012). Critical Thinking Assessment predicts real-world outcomes of critical thinking, Applied Cognitive Psychology, 26(5): 721-729.

Clayton, B. M., \& Van Staden, C. J. (2015). The impact of social influence pressure on the ethical decision making of professional accountants: Australian and New Zealand evidence: Social influence pressure and ethical decision making. Australian Accounting Review, 25(4), 372-388. https://doi.org/10.1111/auar.12077

Duron, R., Limbach, B., \& Waugh, W. (2006). "Critical thinking framework for any discipline". International Journal of Teaching and Learning in Higher Education, 17(2), 160-166.

Glover, S. M., \& Prawitt, D. F. (2014). Practitioner summary: Enhancing auditor professional skepticism: The professional skepticism continuum. Current Issues in Auditing, 8(2), 1-10

Golshayan., Seyed Mohammad., Ghaffari, Mansoura Sadat., Seyed, Seyed Mohadeseh. (2020). Investigating the Impact of Social Pressures, Commitment, and Personality Traits on Auditors' Judgments, Journal of Accounting and Management Perspectives, 23 (1): 117-99.

Griffith, E, E., Hammersley, J, S., Kadous, K., Young, D. (2014). Auditor Mindsets and Audits of Complex Estimates, Journal of Accounting Research, 53(1): 4977. https://doi.org/10.1111/1475-679X.12066

Grossman, A, M., Welker, R, B. (2011). Does the Arrangement of Audit Evidence According to Causal Connections Make Auditors More Susceptible to Memory Conjunction Errors? Behavioral Research in Accounting, 23(2): 93-115. https://doi.org/10.2308/bria-10063

Imai, Sh., Wei Lin, Ch., Watada, J., Tzeng, G, H. (2008). Rough Sets Approach to Human Resource Development of Information Technology Corporations, IJSSST, 9(2): 31-42.

Jafari-Nasab Kermani, Neda, Mollanazeri, Mahnaz., Rahmani, Ali., Azizkhani, Massoud., Bozorg Asel., Musa. (2019). Identifying and Disclosing Key Audit Issues in the Auditor's Report: Perspectives of Iranian Auditors, Management Accounting and Auditing Knowledge, 8 (29): 229-242. 
Javidi., Kazem, Royaee, Ramazan Ali., Talebnia, Qudratullah., Bani Mahd, Bahman (2018). Investigating the Impact of Interpretation Trend on Auditor's Judgment and Decision Making: Based on Psychological Distance Interpretation Level Theory, Financial Accounting Quarterly, 39 (3): 161-149.

Kirmizia, F. S., Saygib, C., Yurdakalc, I. (2015). Determine The Relationship Between The Disposition of Critical Thinking and The Perception About Problem Solving Skills. Procedia - Social and Behavioral Sciences, 191, 657661

Knechel, W. R, Sofla, Amin S., Svanström, T. (2018). The effect of professional skepticism on auditor compensation and auditor opinions. Working Paper, University of Auckland, Business School, Seminars and Events.

Mahmoodi Nasab., Zainab, Bani Mahd., Bahman, Ouhad., Fereydoun. (1396). Study of Social Interaction in the Auditing Profession: Theory of Fair Theory, Accounting Knowledge and Management Auditing, 6 (21): 157-168.

Mauksch, S., Dey, P., Rowe, M. and Teasdale, S. (2017). Ethnographies of social enterprise, Social Enterprise Journal, 13(02): 114-127. https://doi.org/10.1108/SEJ-03-2017-0019

Naeem, M. (2020). Uncovering the role of social motivational factors as a tool for enhancing brand-related content, Qualitative Market Research, 23(2): 287-307. https://doi.org/10.1108/QMR-10-2019-0121

Nasution, D. and Östermark, R. (2012). The impact of social pressures, locus of control, and professional commitment on auditors' judgment: Indonesian evidence, Asian Review of Accounting, 20(2): 163-178. https://doi.org/10.1108/13217341211242204

Olojede, P., Erin, O., Asiriuwa, O., Usman, M. (2020). Audit expectation gap: an empirical analysis, Future Business Journal, 6(10): 111-155. https://doi.org/10.1186/s43093-020-00016-X

Pao, H.-W., Lee, C.-Y., Chung, P.-H. and Wu, H.-L. (2018). Hiring decisions on certified manpower: The resource dependence and social contagion views of institutional innovators, Journal of Advances in Management Research, 15(4): 514-535. https://doi.org/10.1108/JAMR-05-2017-0070

Pawlak, Z. (1982). Rough sets, International Journal of Computer and Information Science, 11(5): 341-356.

Pawlak, Z. (2005). Rough sets and flow graphs, Rough Sets, Fuzzy Sets, Data Mining and Granular Computing, 36(4): 1-11.

Polychronidou, P., Drogalas, G., Tampakoudis, L. (2020). Mandatory rotation of audit firms and auditors in Greece, International Journal of Disclosure and Governance, https://doi.org/10.1057/s41310-020-00080-3 
Preda, A., Muradoglu, G. (2019). Groups, social processes and decision making in finance, Qualitative Research in Financial Markets, 11(4): 429-455. https://doi.org/10.1108/QRFM-08-2017-0073

Putnam, R. D. (1995). Bowling Alon: America Declining Social Capital, Journal of Democracy, 6(1): 65-78.

Robertson, F.A., Samy, M. (2019). Rationales for integrated reporting adoption and factors impacting on the extent of adoption: A UK perspective, Sustainability Accounting, Management and Policy Journal, 11(2): 351-382. https://doi.org/10.1108/SAMPJ-02-2019-0042

Sadeghi Fasaei., Soheila, Aminian, Ehsan. (2016). From Normativeism to Normalization: A Typology of Social Conformity and Qualitative Analysis of Causal Conditions Affecting It, A Study of Iranian Social Issues, 7 (2): 77-104.

Sandelowski, M. \& Barroso, J. (2008) Handbook for synthesizing qualitative research. New York: Springer.

Sepasi., Sahar, Satisfaction, Mahya. (2015). Identifying and ranking the factors affecting social auditing using TOPSIS technique, Financial Accounting Research Quarterly, 28 (4): 127-147.

Shabahang., Reza (2012). Management Accounting, Volume One, Twenty-Third Edition, Accounting and Auditing Research Center, Auditing Organization.

Shyng, J., Wang, F., Tzeng, G., Wu, K. (2007). Rough set theory in analyzing the attributes of combination values for the insurance market, Expert Systems with Applications, 32(1): 56-64

Suyono, E. and Farooque, O. A. (2019). Auditors' professionalism and factors affecting it: insights from Indonesia, Journal of Asia Business Studies, 13(4): 543-558. https://doi.org/10.1108/JABS-03-2018-0073

Tahriri., A., Piri Sagharloo, M. (2016). Auditors' perceptions of professional skepticism in audit work. Accounting and Auditing Review, 23(1), 117-135.

Valiyan, Hassan., Abdoli, Mohammad Reza., Ostadashmi, Ali., Safari Graili, Mehdi. (2019). Designing a Professional Doubt Model Based on Auditors' Mindset and Attitude: Using Foundation Data Analysis, Auditing Knowledge Quarterly, under publication.

Valiyan., Hassan, Safari Graili., Mehdi, Hassanpour, Davood. (2020). Professional and Organizational Identity of Auditors and Commercialization in Auditing Institutions, Auditing Knowledge, 20 (78): 356-391.

Wang, P., Yuan, L., Wu, J. (2018). The joint effects of social identity and institutional pressures on audit quality: The case of the Chinese Audit Industry, International Business Review, 26(4): 666-682. https://doi.org/10.1016/j.ibusrev.2016.12.007

Wardhani, R. (2019). The role of audit quality on market consequences of voluntary 
disclosure: Evidence from East Asia, Asian Review of Accounting, 27(3): 373400. https://doi.org/10.1108/ARA-03-2018-0083

Wu, X., Fan, Y., Yang, Y. (2020). Do critical audit matters signal higher quality of audited financial information? Evidence from asset impairment, China Journal of AccountingStudies, 7(2):170-183. https://doi.org/10.1080/21697213.2019.1676037

Yarahmadi, A. (2018). Investigating the Common Effects of Social Characteristics and Institutional (Organizational) Pressure on Audit Quality, Quarterly Journal of Management and Accounting Studies, 4 (1): 114-133.

Zhang, J., Jiang, Y., Shabbir, R. and Duan, Y. (2015). How perceived institutional pressures impact market orientation: An empirical study of Chinese manufacturing firms, Asia Pacific Journal of Marketing and Logistics, 27(2): 267-293. https://doi.org/10.1108/APJML-02-2014-0033

\section{Bibliographic information of this paper for citing:}

Soleymani, Seyed Mohammad; Dehdar, Farhad \& Abdoli, Mohammadreza (2022). Choosing Influential Dimension of Mindfulness of Auditors'

Professional Judgments Based on Social Pressure: An Analysis Based on Rough Theory. Iranian Journal of Finance, 6(2), 135-166.

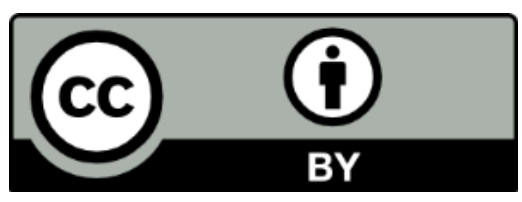

